\title{
E-mail Address for XML File Feedback
}

National Cancer Institute

\section{Source}

National Cancer Institute. E-mail Address for XML File Feedback. NCI Thesaurus. Code C127791.

The E-mail address to which copies of the XML format of the CT application should be sent. 